Built in the 1970s, Village Homes is an extremely successful housing development in Davis, California, and considered a model of sustainable community design. Energy-conscious houses are organized around a system of pedestrian-friendly streets and open spaces, with community facilities, shared gardens, orchards, and vineyards, all managed by residents. Professor Paul Wack, a founder of the Sustainable Environments minor in the College of Architecture and Environmental Design, has been adopting it as a case-study for his classes for several years.

Village Homes is a special place, born out of a tomato farm in the 1970's on the western end of Davis, California, not far from the state's capital where innovation and vision are in short supply. Like an island, Village Homes represents the achievement of a dream that many visitors have had the good fortune to experience, albeit briefly via tour, and commonly share the question: Why are there not more Village Homes?

This question, combined with the many lessons learned over the years as the community matures, provides a wonderful opportunity for our students to experience the implementation side of planning. In fact, the MCRP graduate course on Plan Implementation (CRP 525) has made a field study of Village Homes an annual pilgrimage for several years. For balance, the field day also includes site visits to Aggie Village, a mixed use development in downtown Davis, a tour of infill projects in downtown Sacramento, and concludes with a brief tour of the flawed new urbanist development, Laguna West in Elk Grove.

The field trip is part of a major assignment that includes preparation through readings and research and is completed with a thinking paper submitted by each class member the following week, which is usually rewarding reading for the instructor. The excitement and discussion among the class members at the follow up seminar reflects an enthusiasm that gives a flicker of hope for the future of planning, seasoned with the knowledge that Village Homes is hardly perfect. It reminds us that there are options to the current pattern of "piecemeal planning" as argued by the founders of Village Homes, Michael and Judy Corbett.

Village Homes predates the evolution of smart growth, new urbanism, sustainable development, and green buildings, among other contemporary causes or "flavors of the month". However, Village Homes contains components that many advocates have claimed as part of their alternative development agenda to the status quo. Only the Corbett's can claim legitimate bragging rights to the success (and a few failures) of Village Homes. In addition to the notion that Village Homes offers ideas for sustainable development, the Corbett's have clearly connected Village Homes to the New Urbanism banner through the Ahwahnee Principles, which promote a sense of community, respect for regionalism, and the importance of effective implementation (Corbett and Corbett, 1999)

\section{VILLAGE HOMES: THE SETTING}

This predominately residential 68 acre development is a clearly defined community easily visible from the window of a plane approaching the Sacramento airport. It is surrounded on three sides by conventional subdivisions with agricultural research acreage of the University of California to the immediate south. A significant highlight of Village Homes is its hierarchy of streets, dominated by cul de sac alleys that connect to a system of bicycle/pedestrian paths. Integrated into the development is a diverse scale of open spaces that range from the central village green, orchards, and community gardens to smaller communal parcels of vineyards and small areas for passive recreation and neighbor interaction.

The density of Village Homes is consistent with adjacent developments, although the design of the open spaces suggests otherwise. In addition to some multiple units, the development includes a community center, day care facilities, swimming pool, small offices, apartments, and a restaurant with an outdoor eating area blessed with shade trees to protect diners from the summer heat. Automobiles do not dominate the setting. In fact, when the students visit Village Homes, they are more likely to give way to a jogger, bicyclist, or a group of small children being guided by a couple of adults on their way to some destination on the site with little sense of urgency. 


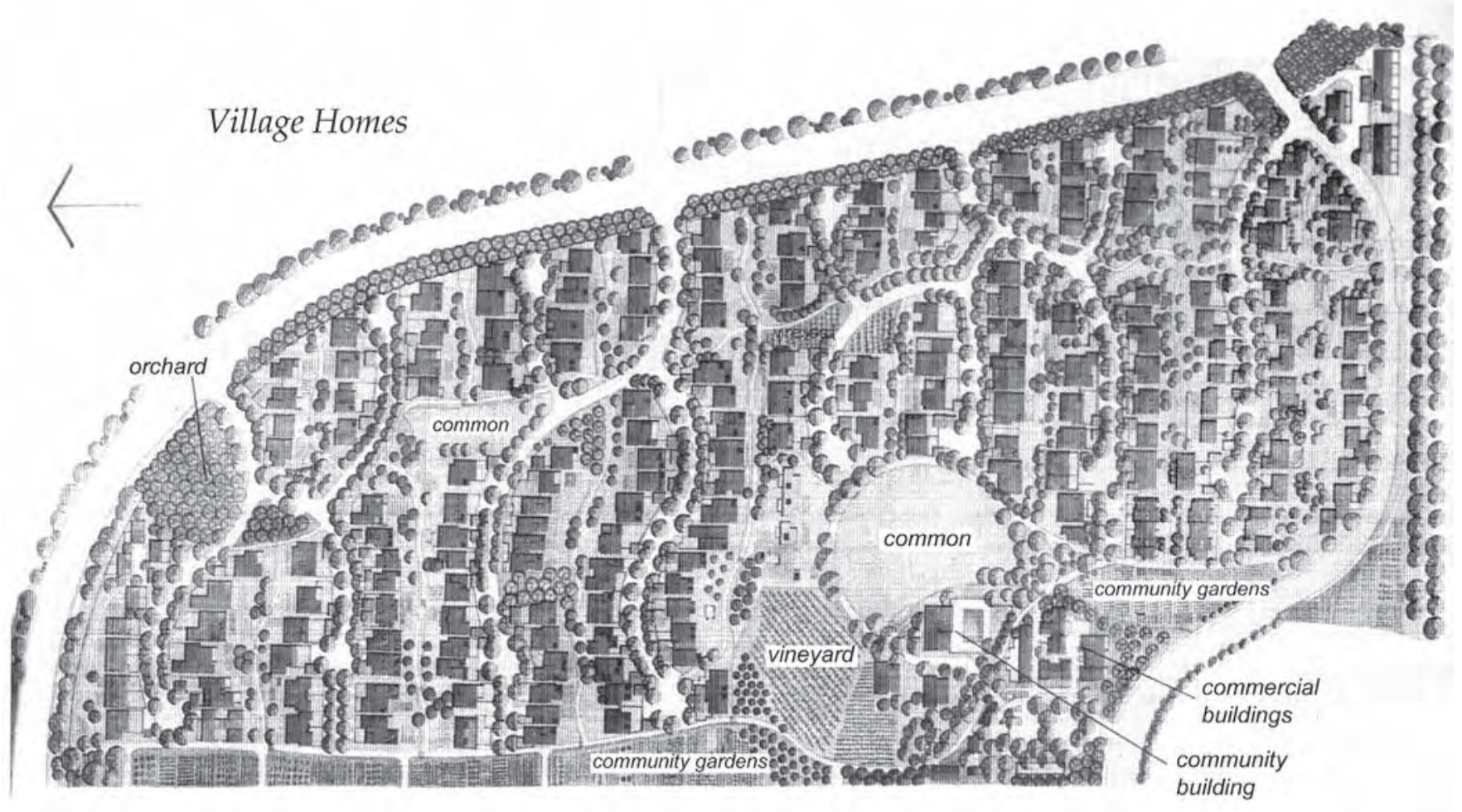

Figure 1. Site plan for Village Homes

The residential structures suggest sustainability. The units face south for solar advantage to provide space and water heating, reducing energy costs. Roof overhangs block summer sun but allow winter solar access. Residences are commonly clustered in groups of seven, with the alley cul de sacs in the rear for cars and eclectic landscaped pathways in the front for people. Missing are traditional gutters and related infrastructure to channel water runoff, including spill over from adjacent developments. Many residential pathways parallel drainage swales that are part of a system designed to protect the entire development from flooding, which has yet to fail.

\section{VILLAGE HOMES AND THE PLANNING PROCESS}

Common sense and the spirit of an innovative idea for the public good suggest that a development with the amenities offered by Village Homes would potentially sail through local planning review, especially with a perceived liberal community like Davis. Unfortunately, the history of the Village Homes development review process represents a classic confrontation between the status quo of conventional zoning standards and a development proposal without the benefit of precedent.

In their book "Designing Sustainable Communities: Learning from Village Homes", Judy and Michael Corbett relive their struggle in the early 1970's in which they had to go political to achieve their vision. With friends, and the spirit of the evolving environmental movement, they formed the Greater Davis Planning and Research Group, dedicated to stopping urban sprawl and the loss of agricultural land. Three candidates for city council at the next election adopted the platform developed by the group, and they won. With the development proposal consistent with the new general plan and a supportive council majority, Village Homes was approved over the objections of city staff, including the planners.

This experience contributes to the learning value associated with Village Homes. Class discussion of innovative zoning techniques (i.e., planned unit developments, specific plans, etc.) suggest how a proposal similar to Village Homes could 


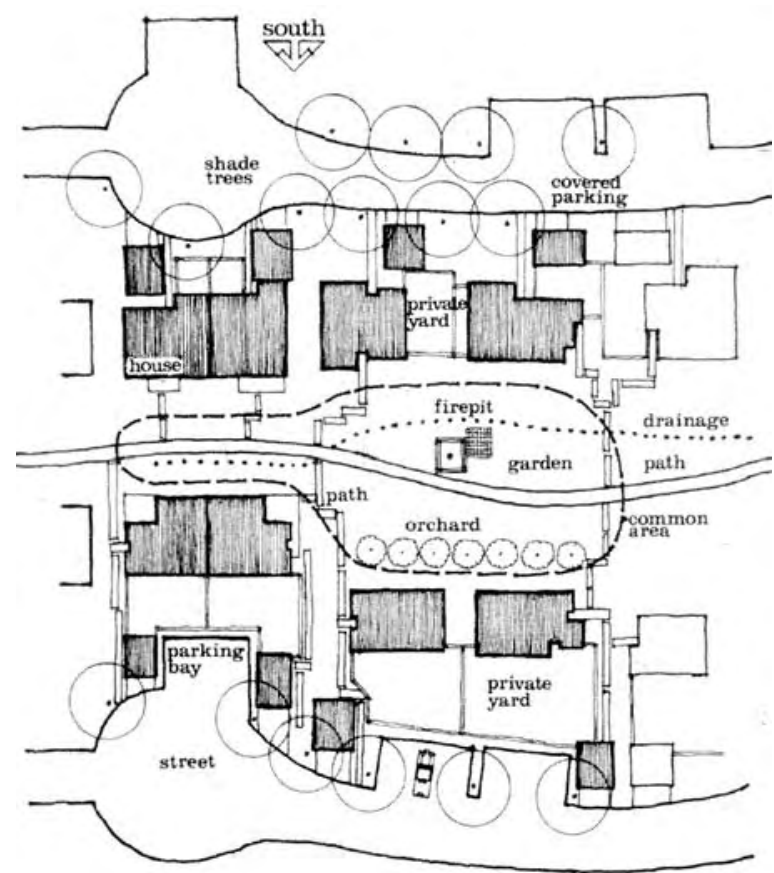

Figure 2. Individual lotting of homes.

successfully achieve discretionary approval, assuming the general plan contains goals, policies, objectives, and implementation programs that provide the "consistency" required for this type of development. It is noteworthy that Michael Corbett is now involved with a controversial 413 acre infill development proposal (Covell Village) at the north end of the city, which incorporates many of the features contained in Village Homes, and ultimately will be subject to a vote of the people within the city. This recent proposal contributes to the dynamic learning opportunities provided by the Village Homes field study.

\section{VILLAGE HOMES AS A LEARNING TOOL}

The bridge between theory and practice is an important feature of our program, and Village Homes serves as an important case study. Additional value to the assignment is the encouragement for our effort by the Local Government Commission (www.lgc.org), in which Judy Corbett is the Executive Director. The LGC provides one of the most popular web sites in the planning world according to Planetizen (www.planetizen.com). Moreover, the tour of Village Homes is hosted by the Local Government
Commission, which in recent years has been represented by a CRP alumnus, Alison Pernell (1999), the winner of the 1999 National APA Distinguished Student Leadership Award.

In short, the synergy of Village Homes, available literature/ internet sources, the Local Government Commission, CRP alumni, and the energy of the participating students serve as an excellent example of how the City and Regional Planning Department has taken the Cal Poly spirit of "learn by doing" to heart in promoting interdisciplinary education. Expanding this educational ideal is represented by the fact that starting Fall Quarter 2005 the CRP Village Homes field trip will include graduate students from the Bren School of Environmental Science and Management at UC Santa Barbara. Building bridges takes many forms and the opportunity for graduate students from different disciplines and programs to meet on a site and discuss planning issues from diverse perspectives is priceless, and can contribute to positive career preparation and development for all involved. Carpe diem!

\section{REFERENCES}

Bainbridge, D., Corbett, J., and Hofacre, J. (1979). Village Homes' Solar House Designs: A Collection of 43 Energy-Conscious House Designs. Emmaus, PA: Rodale Press.

Corbett, J., and Corbett, M. (1999). Designing Sustainable Communities: Learning from Village Homes. Washington, DC: Island Press

Corbett, M. (1981). A Better Place to Live: New Designs for Tomorrow's Communities. Emmaus, PA: Rodale Press.

Francis, M. (2003). Village Homes: A Community by Design. Washington, DC: Island Press.

Jackson, D. (1999, February 22). Back to the Garden: A Suburban Dream. Heroes for the Planet Series. Time 78-9.

Martineau, P. (2004, October 5). Debate is Heated on Davis Housing. Sacramento Bee. Retrieved October 6 2004, from http: //www.sacbee.com/content/news/story/ 10983915p-11901238c.html 


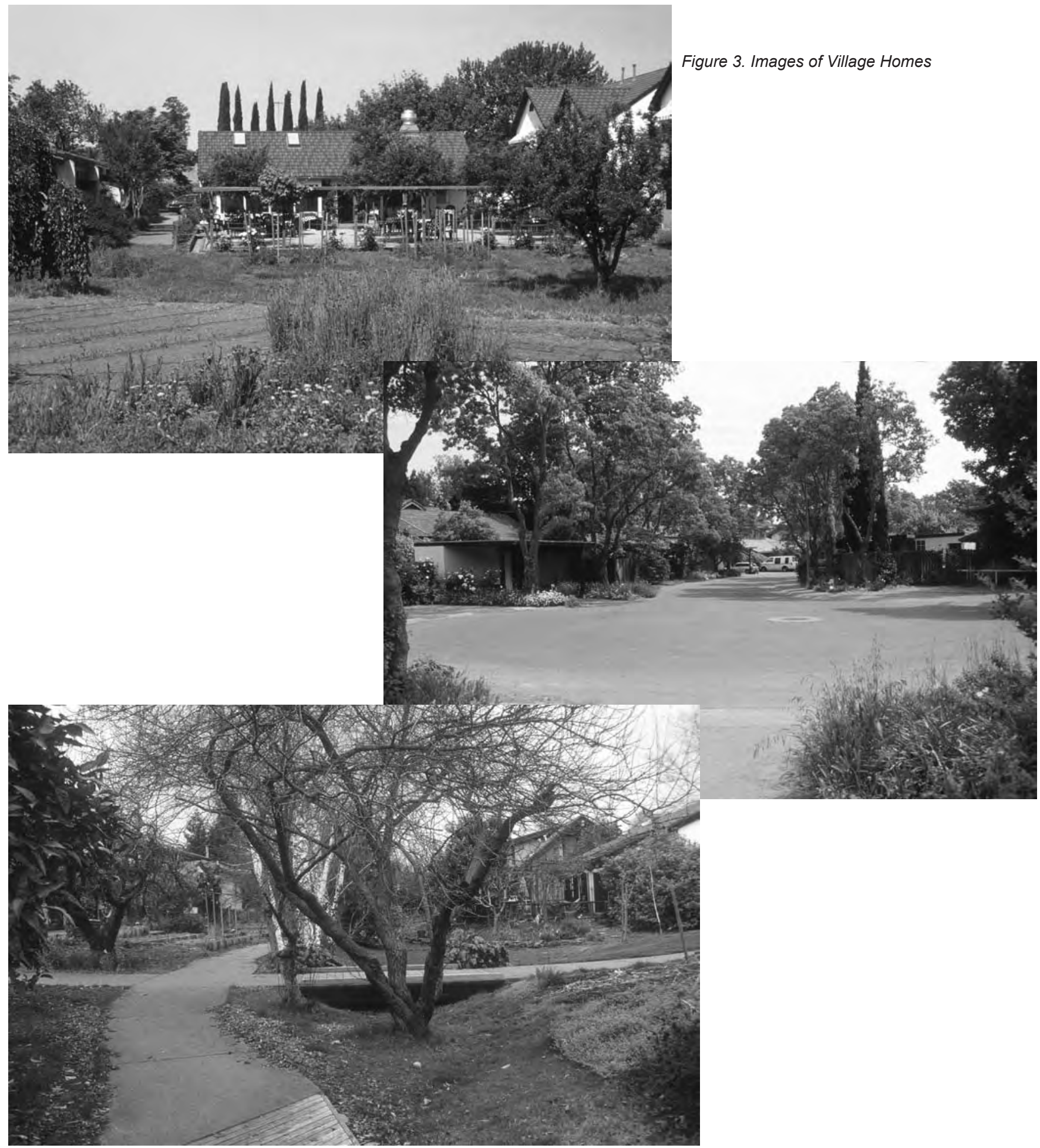

